\title{
CONSERVATIVE STATUS OF FRESHWATER HABITATS OF EUROPEAN COMMUNITY IMPORTANCE FROM ROMANIA
}

\author{
$\underline{\text { Simona Mihăilescu }}^{1}$, Daniela Strat ${ }^{2}$ \\ 1/nstitute of Biology Bucharest, 296 Splaiul Independenței, Bucharest 060031 , \\ biodiversitateibb@gmail.com \\ 2University of Bucharest, Faculty of Geography, 1 Nicolae Bălcescu, Bucharest, \\ 010041, danielastrat@gmail.com, Romania
}

\begin{abstract}
In this paper we present the conservative status of the freshwater habitats based on available data that were resulted from the first monitoring of conservative status of the habitats and species of the Community interest from Romania. This has been achieved during the 20112015 period as an obligation arising from Article 11 of the Habitats Directive (HD) in order to report the summarized and analysed results to the European Commission, according to Article 17 of the directive that requires Member States to report every six years the progress made with the implementation of the HD. As a consequence of geographical position and diversity of landforms, on the Romanian territory overlap five biogeographical regions: Alpine, Continental, Pannonian, Steppic, and the Black Sea (Pontic). The great heterogeneity of landscape is reflected by the diversity of wildlife and natural habitats, including 10 freshwater habitat types of Community importance. The assessment of the conservation status of all freshwater habitat types was carried out following the methodology agreed by the European Commission and Member States. The results, included as part of Romania's first 6-yearly report to the EU from 2013, show that the conservative status is favourable for 8 habitat types, and unfavourable/inadequate for 2 habitat types. Regarding to the "31A0 Transylvanian hotspring lotus beds" priority habitat that occur only in Romania, Pannonian biogeographical Region, its conservative status changed suddenly from favourable before 2013 to unfavourable/bad starting with 2014 because the natural water source of the Peţea Lake was heavy disturbed by recent anthropogenic activities.
\end{abstract}

Keywords: Habitats Directive, Natura 2000, National Report under Article 17, priority habitats, Site of Community Importance

\section{Introduction}

In Romania, the first preoccupations related to nature protection can be found in the late of the $19^{\text {th }}$ - century [1] but a real "preserving nature" movement - plant and animal species as well as outstanding landscapes and natural monuments - has become more focused starting with the beginning of the $20^{\text {th }}$ century. As a result, in 1920 was founded the first association of natural protection from Romania, followed by another one that was founded by the zoologist Emil Racoviță in 1922 [1] The main goal of these asoociations was to establish natural reserves and national parks in Romania and to militate for creating of a legal framework in order to protect the wild nature [2]. Thus, after the first Congress of the Naturalists from Romania (1928), where it was emphasized the necessity of a law of nature protection, in 1930 it was adopted the Law 213/1930 on the Protection of the Natural Monuments. Based on this law it was created the Commission of Natural Monuments which until 1944 had designed 36 natural reserves and the first national park from Romania - Retezat National Park [3]. 
In the communist period, after the Law 213/1930 was abrogated in 1950 it was replaced by the Environment Protection Act from 1973 (Law no.9/1973). At the end of 1989, in Romania there were 74 national reserves, 482 regional protected areas [4], 21 protected animal species and 15 protected plant species.

Since 1990, following communist regime colapse, Romanian Government has adopted a positive attitude related to European and international strategies for environment protection and biological conservation. Consequently, in January 1990 it was designed 13 national parks, in 1991 Danube delta was registered on UNESCO's World Heritage List [5], and later, in 1998, it was designed Biosphere Reserve Danube Delta [6].

During pre-accesion period to the European Union (EU), as a mandatory requirement, Romania signed and ratified treatise and conventions concerning the protection and nature conservation and a national legislation was created in accordance with the European Union legislation.

In response to a growing concern over the relentless decline and wholesale destruction of natural habitats and wildlife across Europe, and following the Convention on the Conservation of European Wildlife and Natural Habitats (Bern Convention) from 1979 [7], in 1992 it was adopted by all members EU the Council Directive 92/43/EEC on the Conservation of natural habitats and of wild fauna and flora (HD 92/43/EEC) [8].

Based on the these two EU nature Directives, every Member State is required to take similar measures in order to conserve the species and habitats listed in their annexes, which are present in their country. The Habitat Directive defines habitats of Community Interest as those that (1) are in danger of disappearance in their natural range; (2) have a small natural range following their regression or by reason of their intrinsically restricted area; or (3) present outstanding examples of typical characteristics of one or more biogeographical regions [8].

The Annex I of the HD92/43/EEC lists habitats which the member states must protect by the designation and management of protected areas that are named Site of Community Importance (SCI).

The original list of habitats was based on the CORINE biotopes classification [9]. It has grown with each extension of EU, from 170 in 1992 to 231 in 2007 [10] and 233 since 2013, after Croatia became member EU [11]. From them, 71 are priority habitats (those indicated with an asterisk in annex I and subject to stricter protection than remaining habitats), which mean they are habitat types in danger of disappearance and whose natural range mainly falls within territory of the European Union. The habitats are defined by vegetation, but abiotic characteristics are included in their name.

With every enlargement of EU, the Annex I was subject of several amendments and completions. Thus, the interpretation Manual from 1996 introduced "Nature 2000 codes" for each habitat type from both CORINE and Palaearctic classifications [10]. In the further editions of the Interpretation Manual, with new added habitats due to enlargement of EU, the CORINE codes were omitted and descriptions of new habitats were based mainly on Palaearctic classification [10], followed by a code(s) based on "A classification of Palaearctic habitats" [12]. A review of all previous editions of Annex I and Interpretation Manuals can be found in the newest version, published in 2013.

Based on Interpretation manual of European Union habitats - EUR 27 [13] Romania published its own manual to the habitats of annex I, which is not just a "mot à mot" translation of the EU guidance [14], [15]. Thus, for each habitat type listed on Annex I of HD92/43/EEC is given the correspondence with national classification of habitats, according to Doniță et al. (2005) [16] and Doniţă et al. (2006) [17]. Furthermore, as a part of assessement and monitoring activity of conservative status of habitats of Comunity interest from Romania, for every habitats category was published a separate guide [18], [19], [20]. 
Article 17 of the habitats directive requires member states to report on its implementation every six years. The national reports includes assessments of each annex I habitat present in the country following an agreed methodology. Each habitat is assessed within every biogeographical region where it occurs in that country, based on assessment of four parameters (habitat range, area, specific structures, and functions and future prospects), separately, according to a "traffic-light scheme" as "favourable" (green), "unfavourable-inadequate" (amber), "unfavourable-bad" (red) or "unknown" (grey). These scores are combined to give an overall assessment for a particularly biogeographical region.

Then ratings of all regions are aggregated in a final score for the EU member State [21]. After the national reports are submitted, the European Topic Centre on Biological Diversity prepares assessments for each biogeographical region at EU-level based on data provided by Member States in their reports.

At European level, the first national reports were for the period 1994-2000, but they were primarily focused on transposition of the Directive into national laws and the progress towards identifying and designating Special Areas of [21]. The next two reports, for the periods 2001-2006 and 2007 - 2012, included assessments on the conservation status of the habitats and species of Community interest. The results of implementation of HD92/43/EEC as a common effort and commitment of each member state to conserve the biodiversity of Europe were emphasised by [22], and one of them is that the area protected for nature conservation in the EU has more than tripled, which is very impressive because it equivalent in size to Germany, Poland and the Czech Republic combined.

Starting with 2007, in Romania has been designated Natura 2000 network, which nowadays comprise 531 sites that cover an area of $55674 \mathrm{~km}^{2}$ [23].

In this paper we present the conservative status of freshwater habitats from Romania based on data from the first National report of Romania according to Article 17 of the Habitats Directive since it is EU member state.

\section{Materials and Methods}

In order to prepare the first National report under Article 17 of HD92/43/EEC since Romania is EU member state, the Institute of Biology Bucharest, Romanian Academy, in partnership with the Ministry of Environment, Waters and Forests, during 20112015 period carried out the project called "Monitoring the conservation status of species and habitats in Romania under Article 17 of the Habitats Directive" that was funded by Sectoral Operational Programme "Environment", Priority axis 4 (http://www.ibiol.ro/posmediu/index.htm).

The project presented national importance, the data gathered by the monitoring program enabling Romania first reports under the Habitats Directive (92/43 / EEC) under the obligations assumed by our country in the Accession Treaty. The project was located throughout the national territory of Romania, the 8 territorialadministrative regions, both within protected natural areas and outside their exclusive economic zone including marine.

At the national level, the assessment activity of conservation status of all habitats listed on Annex I and species listed on Annexes II, IV and V that occur within Romanian territory was performed following the methodology and rules of European Commission which is stated in the two official documents: "Assessment and reporting under Article 17 of the Habitats Directive. Reporting formats for the period 2007-2012" and "Assessment and reporting under Article 17 of Habitats Directive: explanatory Notes \& 
Guidelines,

2012",

both

available

at

http://bd.eionet.europa.eu/activities/Reporting/Article 17/reference portal.

All the collected data from field were stored and processed by a Information System for Monitoring Species and Habitats of Community Interest in Romania (SIMSHAB Sistemul Informatic pentru Monitorizarea Speciilor și Habitatelor de Interes Comunitar). The SIMSHAB was conceived to be a product of the first assessment of conservative status of species (251) and habitats (88) of Community interest in Romania (https://www.simshab.ro) for preparing the national report and also to be a valuable data base that must be used as a benchmark in upcoming assessments and reporting. However, in Romania there are many more types of vegetation and habitats than those listed on HD92/43/EEC Annexes.

Basically, the Natura 2000 database has been used for habitats and species assessments but the sampling was performed outside of Natura 2000 sites, also. Site selection for assessment of habitats and reporting was based on Natura 2000 data base, technical handbooks [18], [19], [20], a Romanian Interpretation Habitats Manual [14] [24], [25] and an agreed assessment matrices for the conservation status of each habitat at local or site level which was aggregated by SIMSHAB (https://www.simshab.ro) [26]. The final National Report under Article 17 in the unique required format for the period 2007-2012 was submitted to the EU Commission, respectively European Environment Information and Observation Network (EIONET) in December 2013 (RO Art.17 2007-2012 Report from 31 December 2013. http://cdr.eionet.europa.eu/ro/eu/art17/envurmdya).

The standing waters group of habitat types is particularly complex because similar vegetation can be found in two or more habitat types. In these cases they can be separated by substrate and water quality expressed by trophic state. As a conclusive example of its versatility is " 3130 Oligotrophic to mesotrophic standing waters with vegetation of the Littorelletea uniflorae and/or of the Isoëto-Nanojuncetea" habitat type which includes two phytosociological classes. Thus, some communities within the class Littorelletea uniflorae can be assessed as "3160 Natural dystrophic lakes and ponds". This relationship among the standing water habitat types driven by water quality and difficulties encountered in the practice of selecting sites was pointed out by Evans [9].

\section{Results and Discussion}

On the Romanian territory overlap five terrestrial biogeographical regions (Alpine, Continental, Steppic, Pannonian and Pontic) and one marine - Marine Black Sea (Fig. 1). According to Interpretation Manual - EUR 28 version, there are 20 freshwater habitats type of Community interest: 10 are standing water type and 10 are running water type. Of all these, on the Romanian territory were identified half of them: 5 standing water types and 5 running water types. Among them, Transylvanian hot-spring lotus beds habitat occurs only in Romania, in Pețea Lake which has an area of only $600 \mathrm{~m}^{2}$ [27] and is located close to Oradea city, Bihor county. Apart from the endemic plant species Nymphaea lotus L. var. thermalis (DC.) Tusz, which is regarded as a Tertiary relict that has survived during ice age time due to the thermal water, in the lake there are another two endemic species and Tertiary relicts [28], [29]. It is about by the gastropod Melanopsis parreyssii (Philippi, 1847) and the fish species Scardinius racovitzai (Müller 1958), which are listed on the IUCN Red List of threatened species as critically endangered [30], [31]. Due to its major biodiversity value, in 1932 Pețea Lake was designed natural reserve [27] and since 2007 it is part of Site of Community Importance - ROSCI0098 Lacul Pețea, because a 
Transylvanian hot-spring lotus beds is a priority habitat. The legal reglementation was from 2007 and upgraded in 2011[32]

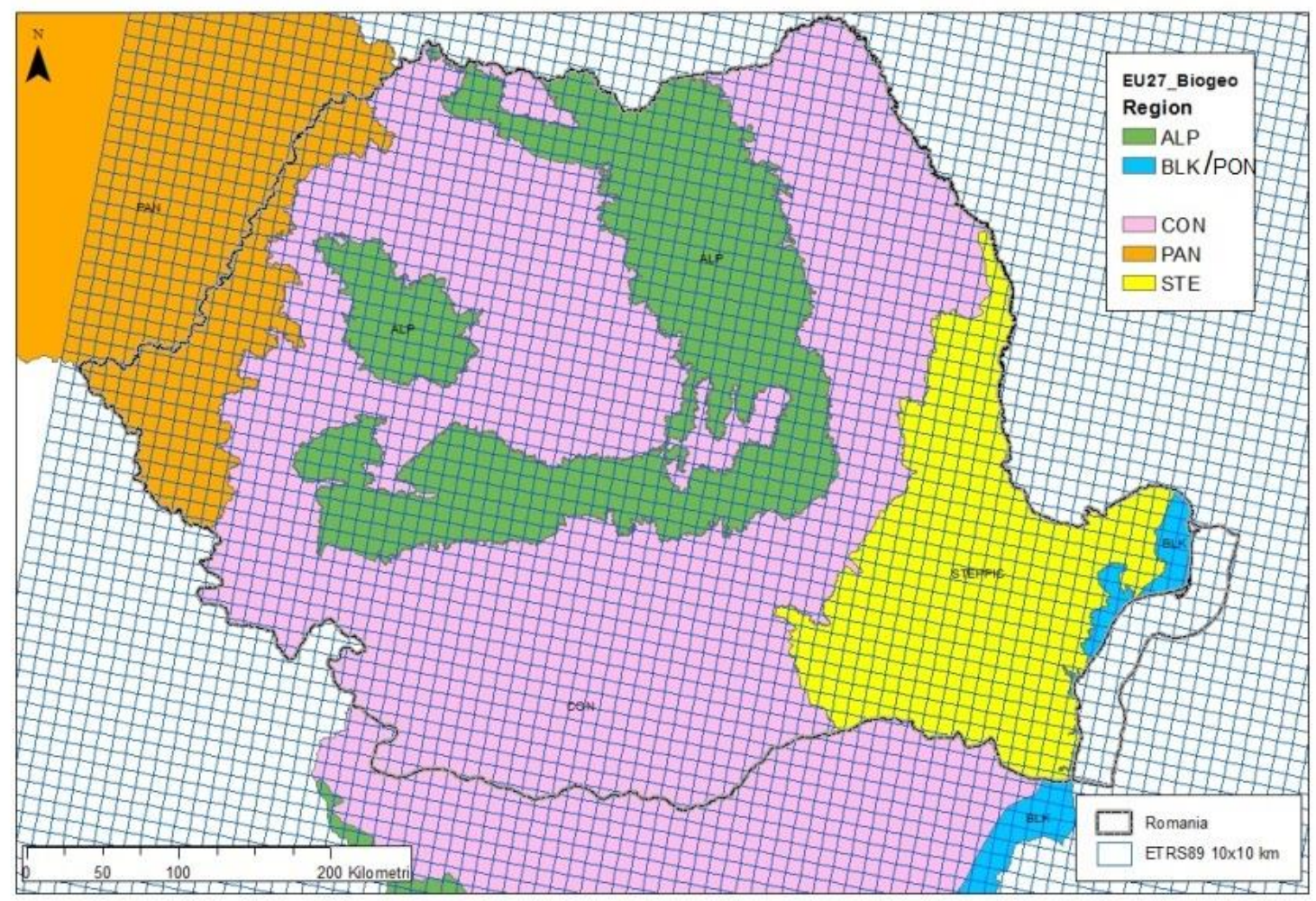

Fig. 1 - The European biogeographical regions in Romania used for Article 17 reporting. Legend: ALP Alpine, BLK Black Sea (Pontic), CON Continental, PAN Pannonian, STP Steppic, MBLK Marine Black Sea, adapted by the from http://bd.eionet.europa.eu/activities/Reporting/Article_17/article17/images/Biogeo_and_Marineregion s March 2013.jpg

All freshwater habitats of Community importance from Romania that were assessed are listed in Table I. Due to Romanian territory is within five biogeographical regions, for every habitat type a separate assessment was carried out for each biogeographical region where it was identified. The result of assessment of conservation status was represented on the Romanian map, which shows boundaries of the biogeographical regions, with the corresponding color code according to "traffic-light scheme". Also, in each biogeographical region it was mapped the occurrence area where the habitat was sampled.

The conservative status of freshwater habitats of Community importance from Romania for the period 2007-2012 reflect data from the official Report to the European Environment Agency European Environment Information and Observation Network on 31 December 2013 [33], [34]. 
Table I. Conservative status of freshwater habitats of Community importance from Romania for the period 2007-2012

\begin{tabular}{|c|c|c|c|c|c|c|c|c|c|}
\hline \multirow{2}{*}{$\begin{array}{l}\text { No. } \\
\text { crt }\end{array}$} & \multirow{2}{*}{$\begin{array}{l}\text { Natur } \\
\text { a } \\
2000 \\
\text { code }\end{array}$} & \multirow[t]{2}{*}{ Habitat Name } & \multirow[b]{2}{*}{$\begin{array}{l}\text { Romanian } \\
\text { Equivalent } \\
\text { Classification } \\
\text { (Doniță et al. } \\
\text { 2005) }\end{array}$} & \multicolumn{5}{|c|}{ Conservative Status } & \multirow{2}{*}{$\begin{array}{l}\text { Future } \\
\text { Per- } \\
\text { spective }\end{array}$} \\
\hline & & & & ALP & $\begin{array}{l}\mathrm{CO} \\
\mathrm{N}\end{array}$ & $\begin{array}{l}\text { PA } \\
\text { N }\end{array}$ & PON & STE & \\
\hline 1 & 3130 & $\begin{array}{l}\text { Oligotrophic to } \\
\text { mesotrophic standing } \\
\text { waters with } \\
\text { vegetation of the } \\
\text { Littorelletea uniflorae } \\
\text { and/or Isoeto- } \\
\text { Nanojuncetea }\end{array}$ & $\begin{array}{l}\text { R2211, } \\
\text { R2212, R2213 }\end{array}$ & FV & FV & $\mathrm{FV}$ & FV & $\mathrm{FV}$ & FVU \\
\hline 2 & 3140 & $\begin{array}{c}\text { Hard oligo- } \\
\text { mesotrophic waters } \\
\text { with benthic } \\
\text { vegetation } \\
\text { of Chara spp. }\end{array}$ & R2201 & $\mathrm{N} / \mathrm{A}$ & FV & $\mathrm{N} / \mathrm{A}$ & FV & FV & FVU \\
\hline 3 & 3150 & $\begin{array}{c}\text { Natural eutrophic } \\
\text { lakes with } \\
\text { Magnopotamion or } \\
\text { Hydrocharition - type } \\
\text { vegetation }\end{array}$ & $\begin{array}{l}\text { R2202, } \\
\text { R2203, } \\
\text { R2204, } \\
\text { R2205, R2206 }\end{array}$ & $\overline{F V}$ & FV & $\overline{F V}$ & FV & FV & FVU \\
\hline 4 & 3160 & $\begin{array}{l}\text { Natural dystrophic } \\
\text { lakes and ponds }\end{array}$ & R2207 & $\mathrm{N} / \mathrm{A}$ & $\mathrm{FV}$ & $\overline{F V}$ & $\mathrm{~N} / \mathrm{A}$ & $\overline{F V}$ & $\overline{F V U}$ \\
\hline 5 & $31 \mathrm{AO}^{*}$ & $\begin{array}{l}\text { *Transylvanian hot- } \\
\text { spring lotus beds }\end{array}$ & R2209 & $\mathrm{N} / \mathrm{A}$ & $\mathrm{N} / \mathrm{A}$ & FV & $\mathrm{N} / \mathrm{A}$ & $\mathrm{N} / \mathrm{A}$ & $\overline{F V U}$ \\
\hline 6 & 3220 & $\begin{array}{l}\text { Alpine rivers and the } \\
\text { herbaceous } \\
\text { vegetation along their } \\
\text { banks }\end{array}$ & $\mathrm{R} 4417$ & FV & FV & $\mathrm{N} / \mathrm{A}$ & $\mathrm{N} / \mathrm{A}$ & $\mathrm{N} / \mathrm{A}$ & $\overline{F V U}$ \\
\hline 7 & 3230 & $\begin{array}{l}\text { Alpine rivers and their } \\
\text { ligneous vegetation } \\
\text { with Myricaria } \\
\text { germanica }\end{array}$ & R4415 & $\mathrm{FV}$ & $\mathrm{N} / \mathrm{A}$ & $\mathrm{N} / \mathrm{A}$ & $\mathrm{N} / \mathrm{A}$ & $\mathrm{N} / \mathrm{A}$ & FVU \\
\hline 8 & 3240 & $\begin{array}{l}\text { Alpine rivers and their } \\
\text { ligneous vegetation } \\
\text { with Salix elaeagnos }\end{array}$ & R4417 & U1 & $\mathrm{N} / \mathrm{A}$ & $\mathrm{N} / \mathrm{A}$ & $\mathrm{N} / \mathrm{A}$ & $\mathrm{N} / \mathrm{A}$ & U1U \\
\hline 9 & 3260 & $\begin{array}{l}\text { Water courses of } \\
\text { plain to montane } \\
\text { levels with the } \\
\text { Ranunculion fluitantis } \\
\text { and Callitricho- } \\
\text { Batrachion vegetation }\end{array}$ & R2208 & FV & FV & U1 & U1 & $\mathrm{FV}$ & U1U \\
\hline 10 & 3270 & $\begin{array}{l}\text { Rivers with muddy } \\
\text { banks with } \\
\text { Chenopodion rubri } \\
\text { p.p. } \\
\text { and Bidention p.p. } \\
\text { vegetation }\end{array}$ & R5312 & $\mathrm{N} / \mathrm{A}$ & $\overline{F V}$ & FV & $\overline{F V}$ & $\overline{F V}$ & $\overline{F V U}$ \\
\hline
\end{tabular}

Based on National report under article 17, delivered to European Commission in December 2013 [24], [31], in Romania the overall conservation status of all freshwater stagnant habitats was reported as "favourable" with future prospects "favourable", too [32]. Except the priority habitat $31 \mathrm{AO}^{*}$ (Transylvanian hot-spring lotus beds), the all other stagnant freshwater habitat types occur in more one biogeographical region 
(Table I). Unfortunately, in the meanwhile, because of natural and anthropogenic causes, combined with an ineffective management of the ROSCI ROSCI0098 Lacul Pețea Nature 2000 site, conservative status of this habitat has dramatically changed from "favourable" to "unfavourable bad". Overexploitation of thermal water for touristic resort has resulted in substantial decrease of Pețea stream that fed the lake [25]. As a consequence, Pețea Lake was almost completely dried up in 2014 [24], [25], [27]. Concerning running freshwater habitats, three of them have been assessed as favorable, two as unfavorable inadequate, and all with unknown tendency. It should be emphasized that in case of "3220 Alpine rivers and the herbaceous vegetation along their banks" habitat type, it occurrence within Continental biogeographic region is determined exclusively by demarcation of Alpine region over Romania territory. Given that the Banat Mountains have an average altitude around $1000 \mathrm{~m}$, they were not included in Alpine region although the Poaina Ruscă Mountains, which also are low altitude mountains, are part of that. Thus, the sites with "3220 habitat" located in Banat Mountains are assigned to the Continental region, not to Alpine.

For the "3260 Water courses of plain to montane levels with the Ranunculion fluitantis and Callitricho-Batrachion vegetation" habitat type, which is spread in all five terrestrial biogeographical regions, the conservative status was assessed as Favourable for Alpine, Continental and Steppic regions, and Unfavourable inadequate within Pannonian and Black Sea region (Pontic).

The main threats to freshwater habitats are anthropogenic activities: pollution, cultural eutrophication, gravel extraction, dredging, stream damming and drainage of wetlands. Future pressures on fresh waters habitats will probably increase.

Many changes in land-use, the lowering of the ground-water table or intensification of land use usually also result in indirect eutrophication, which is a major player in the conservation status of stagnant freshwater habitats. Agricultural nutrients, pesticides and fish farmland activities, deforestation are can impact water quality and biodiversity of habitats.

Alien and invasive species as well as climate change may in the long term be important factors changing the species composition and possibly the functional relationships of the habitats of community interest from Romania.

\section{Conclusions}

According to Romanian version of Interpretation Manual - EUR 27, in Romania have been identified 10 freshwater habitat types of Community interest. Among them, $31 \mathrm{~A} 0 *$ Transylvanian hot-spring lotus beds is listed as a priority habitat that need a stronger protection.

After implementation of the "Monitoring the conservation status of species and habitats in Romania under Article 17 of the Habitats Directive" project, in order to prepare the first National Report delivered in December 2013, the finding results show that conservative status is "favourable" for all standing water habitats group within all biogeographical regions where they occur. Related to running water habitats, for three of them, the conservative status is Favorable in each biogeographical region. For one habitat the conservative status was assessed as Unfavourable-Inadequate in both biogeographical regions where it occurs. The other one was assessed as favourable in three biogeographical regions and Unfavourable-Inadequate in another two. Overall, these results reveal that in Romania freshwaters habitats of Community interest have a favorable conservative status. 


\section{Acknowledgements}

This paper presents partial results from two projects: POS SMIS 17655 and RO 1567IBB04/2016.

\section{References}

[1] Pop, E., Sălăgeanu N., (1965), Monumente ale naturii din România, Editura Meridiane, București.

[2] Borza, Al., (1927), Ne trebuie o lege pentru protecția naturii,Tipografia naţională S.A. Cluj. [3] Otiman, P.I., Dutu, M., Ionescu, C., Vlaic, I. (2014), Parcul Național Retezat - o problemă juridică nerezolvată, Academica, 3, 1-16.

[4] Bleahu, M., (2016), La 25 ani de „mediu” instituţionalizat. [Online] Available at: http://www.mentineromaniacurata.ro/images/prez25/mesaj mbleahu.pdf [Accessed August16 2016].

[5] World Heritage Committee, (1991), http://whc.unesco.org/archive/1991/sc-91-conf00215e.pdf. http://whc.unesco.org/en/decisions/3528/.

[6] http://www.unesco.org/new/en/natural-sciences/environment/ecologicalsciences/biosphere-reserves/europe-north-america.

[7] Convention on the Conservation of European Wildlife and Natural Habitats, European Treaty Series - No. 104, Bern, 19.IX.1979.

[8] Directive 92/43/EEC on the Conservation of natural habitats and of wild fauna and flora

[9] Evans, D., (2006), The Habitats of the European Union Habitats Directives. Biology \& Environment: Proceedings of the Royal Irish Academy, 106 B (3), 167-173. DOI: 10.3318/BIOE.2006.106.3.167

[10] Evans, D., (2010), Interpreting the habitats of Annex I - Past, present and future. Acta Botanica Gallica: bulletin de la Société botanique de France, 157(4), 677-686.

[11] Anon., 2013. Interpretation Manual of European Union Habitats - EUR 28, European Comission, DG Environment.

[12] Devillers, P. \& Devillers-Terschuren, J., (1996), A classification of Palaearctic habitats, Strasbourg: Council of Europe.

[13] Anon., (2007), Interpretation Manual of European Union Habitats - EUR 27, European Comission, DG Environment. http://ec.europa.eu/environment/nature/legislation/habitatsdirective/docs/2007 $07 \mathrm{im}$. pdf

[14] Gafta, D. \& Mountford, O., (2008), Manual de interpretare a habitatelor Natura 2000 din România, Editura RISOPRINT, Cluj Napoca.

[15] Evans, D., Arvela, M., (2011), Assessment and Reporting under Article 17 of the Habitats Directive-Explanatory Notes \& Guidelines for the Period 2007-2012. Final Draft, July 2011, European Topic Centre on Biological Diversity, Paris.

http://circa.europa.eu/Public/irc/env/monnat/library?l=/habitats reporting/reporting 20072012/reporting guidelines/guidelines-finalpdf/

[16] Doniță, N. et al.,( 2005), Habitatele din România, Editura Tehnică Silvică, București.

[17] Doniță, N. et al., (2006), Modificări conform amendamentelor propuse de România și Bulgaria la Directiva Habitate (92/43/EEC), Editura Tehnică Silvică, București.

[18] Zaharia, T. (Ed.), (2013), Ghid sintetic de monitorizare pentru speciile marine și habitatele costiere și marine de inters comunitar din România, Editura Boldaș, Constanța.

[19] Biriș, I.-A. et al., (2013), Ghid sintetic de monitorizare pentru habitatele de interes comunitar: tufărișuri, turbării și mlaștini, stâncării, păduri, Editura Universitas, Petroșani.

[20] Trif, C.A., Făgăraș, M.M., Hîrjeu, N.-C., Niculescu, M., (2015), Ghid sintetic de monitorizare pentru habitatele de interes comunitar (sărături, dune continentale, pajiști, apă dulce din România), Editura Boldaș, Constanța.

[21] Sipkova, Z., Balzer, S., Evans, D. \& Ssymank, A., (2010), Assessing the conservation status of European Union habitats - Results of the community report with a case study of the German national report, Annali di Botanica, Volume 0, 1-19.

[22] Sundseth, K., (2012), The Habitats Directive. Celebrating 20 years of protecting biodiversity in Europe, Luxembourg Office for Official Publications of the European Union. 
[23] Sundseth, K., (2016), Natura 2000 barometer update 2015. Nature and Biodiversity Newsletter Natura 2000, 40, July, 8-9.

[24] Burescu, P., Coldea, G., Gafta, D., \& Nicolin, A. (2008), Ape curgătoare. În D. Gafta, \& O. Mountfor (Ed.), Manual de interpretarea a habitatelor Natura 2000 din România (pg. 29-32), Editura RISOPRINT, Cluj Napoca.

[25] Burescu, P., Oprea, A., \& Sârbu, I. (2008), Ape stătătoare. În D. Gafta, \& O. Mountford (Ed.), Manual de interpretarea a habitatelor Natura 2000 din România (pg. 27-29), Editura RISOPRINT, Cluj Napoca.

[26] Mihăilescu, S., Strat, D., Cristea, I. \& Honciuc, V., (2015), Raportul sintetic privind starea de conservare a speciilor și habitatelor de interes comunitar din România, Editura Dobrogea, București.

[27] Ilieș, D. C., Buhaș, R., llieș, A., Morar, C., \& Herman, G,. (2015), Nymphaea lotus var. thermalis (Pârâul Pețea Natural Reserve), brand near extinction of the Băile Felix - Băile 1 Mai (Romania) spa tourism system. GeoJournal of Tourism and Geosites, Year VIII, 1(15), 107117.

[28] Munteanu, D., (2010), Probleme de metodologie a conservării biodiversităţii, cu referire particulară la speciile animale, Ocrotirea Naturii, Serie Nouă, 46, 11-30.

[29] Telcean, I. C., \& Cupșa, D. (2013), The drastic decline of fish fauna in the thermal lake of "Baile 1 Mai"(Baile Episcopale, Bihor County, Romania). Pisces Hungarici, 7, 141-142.

[30] Feher, Z. (2011), Melanopsis parreyssii. Retrieved August 20, 2016, from The IUCN Red List of Threatened Species:

http://dx.doi.org/10.2305/IUCN.UK.2011-1.RLTS.T155737A4835365.en.

[31] Freyhof, J. \& Kottelat, M., (2008), Scardinius racovitzai. The IUCN Red List of Threatened Species 2008: e.T19948A9113563.

http://dx.doi.org/10.2305/IUCN.UK.2008.RLTS.T19948A9113563.en. Downloaded on 20 August 2016.

[32]. OMM nr. 2387/2011. Ordinul nr. 2387/2011 pentru modificarea Ordinului ministrului mediului şi dezvoltării durabile nr. 1.964/2007 privind instituirea regimului de arie naturală protejată a siturilor de importanţă comunitară, ca parte integrantă a reţelei ecologice europene Natura 2000 în România. Retrieved from http://lege5.ro/Gratuit/gi3dimrsgq/ordinul-nr-23872011-pentru-modificarea-ordinului-ministrului-mediului-si-dezvoltarii-durabile-nr-1964-2007privind-instituirea-regimului-de-arie-naturala-protejata-a-siturilor-de-importanta-comunitar. On 29 August 2016.

[33] RO Art.17 2007-2012 Report from 31 December 2013. Available at: http://bd.eionet.europa.eu/activities/Reporting/Article 17/Reports 2013/Member State Deliv eries

http://cdr.eionet.europa.eu/ro/eu/art17/envurmdya [34]http://cdr.eionet.europa.eu/Converters/run conversion?file=ro/eu/art17/envurmdya/RO h abitats reports. $x m \mid \& c o n v=350 \&$ source $=$ remote 